\title{
AVAILABLE TREATMENTS FOR TYPE 2 DIABETES: A REVIEW
}

\author{
Sukhvinder Singh Sudan \\ Department of Biotechnology \\ Graphic Era deemed to be University, Dehradun, Uttarakhand, India \\ Bhavika Batra \\ Department of Biotechnology \\ Graphic Era deemed to be University, Dehradun, Uttarakhand, India
}

\begin{abstract}
Diabetes reached the epidemic levels back in 1994 according to the Centre for Disease Control and prevention yet the prevalence of diabetes has touched alarming levels since the start of the $21^{\text {st }}$ century resulting in almost 1 million deaths alone in India. According to a study by the Indian Heart Association, India will have 109 million hyperglycemic individuals by 2035 . Diabetes is caused due a reduced secretion of insulin by the beta cells of the pancreatic islets or due to resistance caused against them by the body. The following review includes the currently used oral drugs and subcutaneously injected insulin for the treatment of diabetes and how they help in diabetes management including the advantages and disadvantages of their use.
\end{abstract}

Keywords - Diabetes, Hyperglycemia, Insulin, Metformin

\section{INTRODUCTION}

Diabetes is a chronic metabolic disorder caused by the under secretion of insulin or by resistance caused towards it by the body. Early onset of diabetes causes symptoms such as excessive thirst, frequent urination and tiredness. Diabetes is almost on the verge of gaining a status of a potential epidemic in India. According to the world health organization the prevalence of type 2 diabetes is increasing at a rate of $6 \%$ per year where as deaths due to diabetes have increased by an alarming $35 \%$ over the last few years. According to a study published in Diabetes Care by Wild et al. (2004), the number of cases of diabetes is set to double from 171 million in 2000 to 366 million in 2030 with the largest significant increase in the Indian subcontinent with up to 79.4 million cases [1, 2]. The reason for this increased prevalence of diabetes in India is a result of various factors such as genetics, environment, obesity, rising urban population and lifestyle changes. Despite these alarming levels of incidence of diabetes, very little studies have been conducted in India on the prevalence of diabetes and those conducted might not prove completely accurate as a result of the amount of diversity in the Indian population which include but not limited to socio-economic background, ethnicity, culture and geographic location. Though studies conducted by Indian Council of Medical Research have stated a lower incidence of diabetes in the northern states of India as compared to Maharashtra and Tamil Nadu [3].

There are a wide variety of factors that increase the risk of diabetes which may include body weight, fat distribution, family history, age and physical inactivity stated by Bellou et al. (2018) [4]. Women with conditions such as polycystic ovarian syndrome are at an increased risk of having diabetes [5]. Diabetes also leads to several other fatal complications such as atherosclerosis, neuropathy, nephropathy, retinopathy, sleep apnea and Alzheimer's disease [8]. Though the number of diabetes cases has increased over the years, there has also been steadfast research to develop pharmaceutical interventions for the management and treatment of the same. Newer and more effective agents have been developed which not only helps in increasing insulin production and decreasing insulin resistance but also proved beneficial in the prevention of heart and kidney diseases, Alzheimer 's disease and certain kinds of cancers as well. All these agents work differently in the body and are prescribed for use at different stages of the disease. Metformin, for example, is used in the early stages of diabetes used in combination with sulfonylureas such as Glimperide where as SGLT-2 inhibitors are used at later stages [10]. Though these drugs have proved potent for the management of diabetes they also inflict a number of side effects in the human body such as weight gain, hypoglycemia, nausea and skin disorders[11]. Apart from these oral drugs, a wide variety of subcutaneously injected insulin prepared with the help of recombinant DNA technology is employed for the management of diabetes. There are several analogs of human insulin present in the market which act differently for glycemic control. Several patients have experienced adverse side effects from synthetic insulin therefore animal based insulin is employed in such cases. Insulin is also listed on the WHO list of essential medicines and in considered an important drug in any healthcare system [12]. The following review article discusses in brief the available treatments for 
type 2 diabetes and what advantages and disadvantages they pose with respect to the human body.

\section{CLASS OF DRUGS USED FOR THE TREATMENT AND MANAGEMENT OF DIABETES}

2.1 Metformin Metformin is a biguanide which is used as the most common drug for the treatment of Type 2 diabetes commonly in patients with obesity. Discovered back in the 1920s it has been used in the USA since 1995 and is listed by the World Health Organization as Essential Medicine. Metformin has been widely accepted all over the world today as the most common treatment for type 2 diabetes but was initially rejected by physicians in the $19^{\text {th }}$ century because of apprehension regarding lactic acidosis[14]. Though the drug has been in use for over a century now new aspects of its affects on the body are still researched upon every day. Various in vitro and in vivo studies in animal models have suggested that metformin is useful for the treatment of various other metabolic disorders such as obesity and non-alcoholic fatty liver disease [15]. Recent studies prove it beneficial in reducing the risk of dementia and various forms of cancer [16, 17]. Metformin acts in the body by various different mechanisms which are non- pancreatic and plays no role in increasing the insulin production. Instead it increases the effect of insulin making the body sensitive towards insulin. Metformin regulated the glucose produced by the liver by activating the enzyme adenosine monophosphate kinase (AMPK) which inhibits the production of key enzymes involved in glycogen synthesis in the liver and invigorating insulin signaling and glucose transport in muscles [18]. Metformin is considered a unique anti hyperglycemic agent because it increases the peripheral glucose disposal without causing hypoglycemia [19].

2.2 Sulfonylureas These are class of organic compounds widely used for the management of Type 2 diabetes mellitus. Sulfonylureas were discovered in 1942 by Janoban et al. and carbutamide was synthesized as a potent drug for type 2 diabetes was later withdrawn from the market because of its unpropitious affects on bone marrow [20]. Sulfonylureas are prescribed to patients only if they are not overweight and metformin treatment has not proved to gain desired glycemic control [21]. Sulfonylureas act by increasing the insulin concentrations in the plasma and prove effective only due to the presence of residual beta cells. The mode of action is a two step procedure where insulin secretion stimulated by pancreatic beta cells is followed by a reduction in the hepatic clearance of insulin. They act by binding on to the specific receptors on the beta cells of the pancreas and obstruct the inflow of $\mathrm{K}^{+}$(potassium) through ATP-dependent channels making the potassium count zero in the beta cells which makes the cell membrane depolarized thereby preventing the diffusion of calcium into the cystol. As the inflow of calcium is increased into the beta cells it stimulated the contraction of actomyosin filaments responsible for insulin exocytosis. Sulfonylureas directly effects the liver and the adipose tissue to stimulate anti diabetic affect by inhibition of triglyceride lipase and lipolysis further inhibiting glucose output and increasing uptake and oxidation of glucose [22, 23].

Table 1: Potential side effects of various classes of anti hyperglycaemic agents

\begin{tabular}{|c|c|}
\hline S.NO. & $\begin{array}{l}\text { Potential antihyperglycemic agents and their } \\
\text { side effects }\end{array}$ \\
\hline 1. & \begin{tabular}{ll}
\multicolumn{1}{l}{ Biguanides } \\
- & Indigestion \\
- & Nausea and Vomiting \\
- & Feeling Weak \\
- & Heartburn. \\
- & Stomach pain \\
- & Diarrhea
\end{tabular} \\
\hline 2. & $\begin{array}{cl}\text { Sulphonylureas } \\
\text { - } & \text { Weight Gain } \\
\text { - } & \text { Dizziness } \\
\text { - } & \text { Hypoglycemia } \\
\text { - } & \text { Dark Urine } \\
\end{array}$ \\
\hline 3. & $\begin{array}{ll}\text { Meglitinides } \\
\text { - Hypoglycemia } \\
\text { - } \quad \text { Nausea and Vomiting } \\
\text { - } \quad \text { Diarrhea } \\
\text { - Headache } \\
\text { - } \quad \text { Joint and back pain }\end{array}$ \\
\hline 4. & $\begin{array}{ll}\text { Thaizolidinediones } \\
\text { - } & \text { Hypoglycemia } \\
\text { - } & \text { Heart failure } \\
\text { - } & \text { Sinus infection } \\
\text { - } & \text { Headache } \\
\text { - } & \text { Sore throat (Pharyngitis) }\end{array}$ \\
\hline 5. & $\begin{array}{l}\text { Dipeptidyl peptidase -4(DPP- 4) inhibitors } \\
\text { - Diarrhea } \\
\text { - Nausea } \\
\text { - Stomach pain } \\
\text { - Upper respiratory infection } \\
\text { - Sore throat } \\
\text { - Skin reactions }\end{array}$ \\
\hline 6. & $\begin{array}{ll}\text { Sodium-glucose transport (SGLT) 2inhibitor } \\
\text { - } & \text { Hyperkalemia (high levels of potassium in } \\
\text { - } & \text { Hypotood) } \\
\text { - } & \text { Ketoacidosis } \\
\text { - } & \text { Urinary tract infections (UTIS) } \\
\text { - } & \text { Increased urination } \\
\text { - } & \text { Kidney problems } \\
\text { - } & \text { Flu like symptoms } \\
\end{array}$ \\
\hline
\end{tabular}




\begin{tabular}{|c|c|}
\hline & $\begin{array}{ll}\text { - } & \text { Constipation } \\
\text { - } & \text { Nasal congestion } \\
\text { - } & \text { Back pain } \\
\text { - } & \text { Skin allergies }\end{array}$ \\
\hline 7. & $\begin{array}{c}\text { GLP-2 receptor agonists } \\
\text { - } \quad \text { Gastrointestinal infections } \\
\text { - } \quad \text { Injection site reactions } \\
\text { - } \\
\text { - } \\
\text { Headache } \\
\text { Nasopharyngitis }\end{array}$ \\
\hline 8. & $\begin{aligned} & \text { Insulin } \\
& \text { - } \text { Weight gain } \\
& \text { - } \text { Lumps and scars } \\
& \text { - } \text { Rash at the site of injection } \\
& \text { - } \text { Swelling of your arms and legs } \\
& \text { - } \text { Dizziness or lightheadedness } \\
& \text { - Hypoglycemia } \\
& \text { - Heart failure }\end{aligned}$ \\
\hline
\end{tabular}

2.3 Meglitinides These compounds were developed in the late 1970s then known as HB 699 by the addition of a $\mathrm{COOH}$ group to the nonsulfonylurea end of the glibenclamide molecule. These are secretagogue molecules are capable of inducing a more rapid anti hyperglycemic response for a shorter duration as compared to sulfonylureas thus reducing the risk of hypoglycemia and lowering post parandial hyperglycemia [24]. Meglitinides act similarly as sulfonylureas but possess different structural pharmacological properties as well as the duration of action. Meglitinides promotes insulin secretion by promoting the inflow of calcium ions into the beta cells by inhibiting potassium inflow through ATP dependent channels resulting in membrane depolarization which results in exocytosis of insulincontaining granules. Meglitinides bind with SUR1 (a component of the beta cell potassium channel) but with less binding affinity as compared to sulfonylureas which results in the closure of the potassium channels. There lower half life period and distinct SUR1 binding site differentiates them from sulfonylureas [25, 26, 27].

2.4 Thiazolidinediones Introduced in the late 1990s for the treatment of type 2 diabetes, TZD are a class of heterocyclic compounds consisting of a five-membered $\mathrm{C}_{3} \mathrm{NS}$ ring. TZD help in reducing insulin resistance in individuals and also reduces the risk of long term cardiovascular complications [28]. Treatment with TZD has also been associated with weight gain because of the increase in subcutaneous fat mass and little or no decrease in visceral fat mass due to an improved glycemic control [29]. TZDs act by activating a group of nuclear receptors known as peroxisome proliferatoractivated receptors (PPAR). Free fatty acids and eicosanoids act as ligands for these receptors. On activation these receptors form a complex with the DNA and a nuclear receptor known as retinoid $\mathrm{X}$ receptor (RXR) which increases the expression of certain genes and decreasing the transcription of certain others. PPAR binds with certain genes on the DNA of the target gene known as peroxisome proliferator hormone response elements (PPREs).[30, 31] As a result of activation of these nuclear receptors there is a decrease in the lipid levels in the body. This activation further promotes a decrease in insulin resistance and a modification in adipocyte differentiation. [32]

2.5 DPP-4 inhibitors Dipeptidyl peptidase 4 inhibitors are a class of hypoglycemics approved by the FDA in 2006 for the treatment of type 2 diabetes. They work by reducing glucagon in the blood and in turn increasing insulin levels[33]. Glucagon-like peptide-1 (GLP-1) and glucose-dependent insulinotropic polypeptide (GIP) are the two main gut hormones also referred to as incretin that are involved in the removal of glucose by stimulating the release of insulin from the pancreas[34]. DPP-4 inhibitors increase incretin levels in the body which delay gastric emptying, reduce glucagon levels and increase insulin production in the body. GLP-1 is a very important enzyme as it helps in the proliferation of beta cells and decreasing beta cell apoptosis [35].

2.6 GLP-2 receptor agonists GLP-2 is a 33 amino acid long peptide produced by the intestinal mucosa in response to the oral nutrient intake. GLP-2 is responsible for the release of insulin stimulated by glucose levels due to nutrient intake. The GLP-2 affect is reduced in patients with diabetes[36]. Recent studies suggest that the deterioration of GLP-1 is related to this reduced effect which further decreases insulin secretion leading to insulin resistance and hyperglycemia[37]. Due to this there is a decrease in the GLP-1 expression finally leading to GLP-1 resistance. GLP agonists work by stimulating GLP-1 thereby increasing insulin secretion in response to the oral nutrient uptake. This will result in improved insulin sensitivity and lower levels of glucagon in the blood [38].

Table 2: Commercial and Generic names of types of anti diabetic drugs

\begin{tabular}{|c|c|}
\hline S.NO. & Commercial and Generic Nmaes \\
\hline 1. & $\begin{array}{ll}\text { Biguanides } \\
\text { - } & \text { Metformin IR (Glucophage) } \\
\text { - } & \text { Metformin SR (Glucophage SR.) } \\
\text { - } & \text { Fortamet } \\
\text { - } & \text { Glutametza } \\
\text { - } & \text { Riomet }\end{array}$ \\
\hline 2. & $\begin{array}{ll}\text { Sulphonylureas } \\
\text { - } & \text { Amaryl (Glimepiride) } \\
\text { - } & \text { Daonil (Gilbenclamide) } \\
\text { - } & \text { Diamicron (Gilclazide) } \\
\text { - } & \text { Diamicron MR (Gilclazide) }\end{array}$ \\
\hline
\end{tabular}




\begin{tabular}{|c|c|}
\hline & $\begin{array}{ll} & \text { Glibenese (Glipizide) } \\
\text { - } & \text { Minodiab (Glipizide) } \\
\text { - } & \text { Tolbutamide (Tolbutamide) }\end{array}$ \\
\hline 3. & $\begin{array}{l}\text { Meglitinides } \\
\text { - } \quad \text { Repaglinide } \\
\text { - Nateglinide }\end{array}$ \\
\hline 4. & $\begin{array}{ll}\text { Dipeptidyl peptidase -4(DPP- 4) inhibitors } \\
\text { - } & \text { Januvia (Sitagliptin) } \\
\text { - } & \text { Galvus (Vildagliptin) } \\
\text { - } & \text { Tralyza (Saxagliptin) } \\
& \text { in the USA (Linagliptin) - approved for use }\end{array}$ \\
\hline 5. & $\begin{array}{cl}\text { Sodium-glucose transport (SGLT) 2inhibitor } \\
\text { - } \quad \text { Forxiga (Dapagliflozin) } \\
\text { - } \quad \text { Invokana (Canagliflozin) } \\
\text { - Jardiance (Empagliflozin) }\end{array}$ \\
\hline 6. & $\begin{array}{l}\text { Thaizolidinediones } \\
\text { - Pioglitazone } \\
\text { - Rosiglitazone }\end{array}$ \\
\hline 7. & $\begin{array}{c}\text { GLP-2 receptor agonists } \\
\text { - Teduglutide }\end{array}$ \\
\hline
\end{tabular}

2.7 SGLT-2 inhibitors Sodium-glucose transport inhibitors also referred to as gliflozins are the newest class of drugs employed for the treatment of type 2 diabetes. It is prescribe to patients in the later stages of hyperglycemia, especially, to those reluctant to the use of insulin[39]. Certain members of this class of drugs have not only shown results for the better management of diabetes but also induced weight loss and reduced blood pressure[40]. Gliflozins are generally used in combination with metformin and sulfonylureas principally in obese individuals to induce weight loss that would benefit the underlying condition[41]. Gliflozins work by inhibiting the SGLT proteins present in the proximal convoluted tubules of the kidney responsible for $80-90 \%$ glucose reabsorption filtered by the glomerulus of the kidney. By inhibiting these proteins, gliflozins avert the reuptake of glucose by the kidney and promoting glucosuria thereby lowering glucose levels in the blood $[42,43]$. Recent studies have shown that SGLT-2 inhibitors significantly reduces HbA1c levels, weight and blood glucose level without causing any threat to cardiovascular safety[44].

2.8 Insulin Insulin is a polypeptide molecule which consists of two chains A and B linked together by sulphide bonds. Insulin comprises of 51 amino acids with A chain having 21 amino acids and B having 30 amino acids. Insulin is a hormone secreted by the beta cells of the pancreatic islets of langerhans responsible for maintaining normal blood glucose levels in the body [45]. Due to the prevalence of diabetes to a level where today it has become an epidemic, the use of insulin therapy for the management of hyperglycemia is being employed widely all over the world. Many synthetic analogues of human insulin are available in the market today developed with the help of Recombinant DNA technology. Insulin initiate its affect by binding to the receptor molecules comprising of alpha and beta subunits present in the cell membrane. A homodimer is formed as a result of the joining of the two molecules. Insulin binds to the alpha subunits on the extracellular side of the cells. As insulin binds with the Beta subunit, it triggers the release of tyrosine kinase enzyme . This results in auto phosphorylation of beta subunits further leading to the phosphorylation of proteins known as insulin receptor substrates (IRS). Due to the phosphorylation of IRS various other transcription factors and kinases are activated which mediate the intracellular effects of insuin. Termination of this signaling is initiated because of endocytosis, degradation of insulin receptor bond and dephosphorylation of tyrosine residues. These effects of insulin result in an increase uptake of glucose by the cells, DNA replication and protein synthesis [46].

\section{CONCLUSION}

Type 2 diabetes is a global epidemic which has resulted in the deaths of millions of people while causing irreparable damage to the health and lifestyle of many. The increased prevalence of this disorder in both developed and developing countries has been directly linked to the unhealthy lifestyle and obesity that has rooted deep into our modern society. Early detection and management of diabetes has proved to be beneficial for a majority of people accompanied by exercise and intake of fresh fruits and vegetables. A wide number of oral pharmaceutical agents have proved to work efficiently in the management of diabetes though a permanent cure still remains at large. A wide number of epidemiological studies and surveys need to be conducted specially in diverse and densely populated countries like India to check the prevalence of the disease. Governments and organizations also need to create a health infrastructure where people from all kind of socioeconomic backgrounds can avail the necessary treatment for diabetes. Research in the area of plant based herbal drugs should also be encouraged to develop products and combinational therapies for the management of hyperglycemia. Many research studies involving tissue engineering and stem cell technology for developing viable treatments for diabetes are underway and positive results are expected.

\section{ACKNOWLEDGEMENT}

We would like to extend our sincere gratitude to our parents and mentors for their continuous support and suggestions.

Conflict of Interest: The authors declare no conflict of interest. 


\section{REFERENCE}

[1]Wild S, Roglic G, Green A, Sicree R, King H. (2004). Global prevalence of diabetes: estimates for the year 2000 and projections for 2030, Diabetes Care, (pp. 1047-1053).

[2] Kaveeshwar, Seema Abhijeet, and Jon Cornwall. (2014). The current state of diabetes mellitus in India, The Australasian medical journal, (pp. 145-148).

[3] Anjana RM, Ali MK, Pradeepa R. (2011). The need for obtaining accurate nationwide estimates of diabetes prevalence in India - rationale for a national study on diabetes, Indian Journal of Medical Research, (pp. 369-380).

[4] Bellou V, Belbasis L, Tzoulaki I, Evangelou E. (2018). Risk factors for type 2 diabetes mellitus: An exposure-wide umbrella review of meta-analyses, PLoS One, vol. 13(3).

[5] Wang, Erica. 2011. T.Polycystic ovary syndrome and risk for long-term diabetes and dyslipidemia., Obstetrics and gynecology, (pp. 6-13).

[6] Lo JC, Feigenbaum SL, Yang J, Pressman AR, Selby JV, Go AS J. (2006). Epidemiology and adverse cardiovascular risk profile of diagnosed polycystic ovary syndrome, The Journal of Clinical Endocrinology and Metabolism, (pp. 13571363).

[7] Kapoor D, Bhardwaj AK, Kumar D, Raina SK. (2014). Prevalence of Diabetes Mellitus and its risk factors among permanently settled tribal individuals in Tribal and urban areas in northern state of sub-himalayan region in India, International Journal of Chronic Diseases, (DOI no.380597).

[8] Papatheodorou K, Banach M, Bekiari E, Rizzo M, Edmonds M. (2018). Complications of Diabetes, Journal of Diabetes Research, (DOI no. 3086167).

[9] Bernardi S, Severini GM, Zauli G, Secchiero P. (2012). Cell-based therapies for diabetic complications, International Journal of Experimental Diabetes Research, (DOI no. 872504).

[10] Lajara R. (2014). The potential role of sodium glucose co-transporter 2 inhibitors in combination therapy for type 2 diabetes mellitus, Expert Opinion on Pharmacotherapy, (pp. 2565-2585).

[11] Chaudhury A, Duvoor C, Reddy Dendi VS. (2017). Clinical Review of Antidiabetic Drugs: Implications for Type 2 Diabetes Mellitus Management, Frontiers in Endocrinology (Lausanne), ( doi: 10.3389/fendo.2017.00006).

[12] Swinnen SG, Hoekstra JB, DeVries JH. 2009. Insulin therapy for type 2 diabetes, Diabetes Care, (pp. 253-259) .

[13] McCall AL. 2005. Starting insulin therapy in type 2 diabetes: lesson 1, Current Diabetes Reports, (pp. 325-326).

[14]Stang M, Wysowski DK, Butler-Jones D. (1999). Incidence of lactic acidosis in metformin users, Diabetes Care, ( pp. 925-927).

[15]Kalra S, Dhamija P, Das AK. (2012). "Metformin: Midlife maturity, maiden charm", Indian Journal of Endocrinology and Metabolism, (pp. 1015-1018).

[16] Cheng C, Lin CH, Tsai YW, Tsai CJ, Chou PH, Lan TH. (2014). Type 2 diabetes and antidiabetic medications in relation to dementia diagnosis, The Journals of Gerontology. Series A Biological Sciences and Medical Sciences, (pp. 1299-1305).

[17] Berstein LM (2012). Metformin in obesity, cancer and aging: addressing controversies, Aging (Albany NY), (pp. 320-329).

[18] Matthaei S, Greten H. (1991). Evidence that metformin ameliorates cellular insulin-resistance by potentiating insulininduced translocation of glucose transporters to the plasma membrane, Diabetes and Metabolism, (pp. 150-158).

[19] Rösen P, Wiernsperger NF. (2006). Metformin delays the manifestation of diabetes and vascular dysfunction in GotoKakizaki rats by reduction of mitochondrial oxidative stress, Diabetes Metabolism Research and Reviews,( pp. 323$330)$.

[20] Sola D, Rossi L, Schianca GP. (2015). Sulfonylureas and their use in clinical practice, Archives of Medical Science, (pp. 840-848).

[21] American Diabetes Association. (2013). Standards of medical care in diabetes-2013, Diabetes Care, (pp. 11-66).

[22] Lebovitz HE, Feinglos MN. (1978). Sulfonylurea drugs: mechanism of antidiabetic action and therapeutic usefulness", Diabetes Care, (pp. 189-198).

[23] Sola D, Rossi L, Schianca GP. (2015). Sulfonylureas and their use in clinical practice, Archives of Medical Science, (pp. 840-848).

[24]Guardado-Mendoza, Rodolfo \& Prioletta, Annamaria \& Jiménez-Ceja, Lilia \& Aravind, Sosale \& Folli, Franco. (2013). The role of nateglinide and repaglinide, derivatives of meglitinide, in the treatment of type 2 diabetes mellitus, Archives of medical science, (pp. 936-943).

[25] S.M. Blackman, D.W. Cooke, Encyclopedia of Biological Chemistry (Second Edition), 2013

[26] Landgraf R. (2000). Meglitinide analogues in the treatment of type 2 diabetes mellitus, Drugs Aging, (pp. 411425).

[27] Culy CR, Jarvis B. (2001). Repaglinide: a review of its therapeutic use in type 2 diabetes mellitus, Drugs, (pp. 16251660).

[28]Lebovitz HE. (2019). Thiazolidinediones: the Forgotten Diabetes Medications, Current Diabetes Reports, (pp. 151).

[29] Nesto RW, Bell D, Bonow RO. (2003). Thiazolidinedione use, fluid retention, and congestive heart failure: a consensus statement from the American Heart Association and American Diabetes Association, Circulation, (pp. 2941-2948).

[30] Thangavel, Neelaveni. (2017). Targeting Peroxisome Proliferator-Activated Receptors Using Thiazolidinediones: Strategy for Design of Novel Antidiabetic Drugs, International journal of medicinal chemistry (https://doi.org/10.1155/2017/1069718).

[31] Brown JD, Plutzky J. (2007). Peroxisome proliferatoractivated receptors as transcriptional nodal points and therapeutic targets, Circulation, (pp. 518-533). 
[32] Evans RM, Barish GD, Wang YX. (2004). PPARs and the complex journey to obesity, Nature Medicine, (pp. 355361).

[33]Pathak, Rolee, and Mary Barna Bridgeman. (2010). Dipeptidyl Peptidase-4 (DPP-4) Inhibitors In the Management of Diabetes, Pharmacy and therapeutics, ( pp. 509-13).

[34] Verspohl EJ. (2009). Novel therapeutics for type 2 diabetes: incretin hormone mimetics (glucagon-like peptide-1 receptor agonists) and dipeptidyl peptidase-4 inhibitors, Pharmacology and Therapeutics, (pp. 113-138).

[35] Neumiller JJ. (2009). Differential chemistry (structure), mechanism of action, and pharmacology of GLP-1 receptor agonists and DPP-4 inhibitors, Journal of American Pharmacists Association, (pp. 16-29).

[36]Nauck M, Stöckmann F, Ebert R, Creutzfeldt W. (1986). Reduced incretin effect in type 2 (non-insulin-dependent) diabetes, Diabetologia, (pp. 46-52).

[37] Calanna S, Christensen M, Holst JJ. (2013). Secretion of glucose-dependent insulinotropic polypeptide in patients with type 2 diabetes: systematic review and meta-analysis of clinical studies, Diabetes Care, (pp. 3346-3352).

[38]Zander M, Madsbad S, Madsen JL, Holst JJ. (2002). Effect of 6-week course of glucagon-like peptide 1 on glycaemic control, insulin sensitivity, and beta-cell function in type 2 diabetes: a parallel-group study, Lancet, (pp. 824-830). [39]Shubrook, Jay; Baradar-Bokaie, Babak; Adkins, Sarah. (2015). Empagliflozin in the treatment of type 2 diabetes: Evidence to date, Drug Design, Development and Therapy, (pp. 5793-5803).

[40]Haas, B.; Eckstein, N.; Pfeifer, V.; Mayer, P.; Hass, M D S. (2014). "Efficacy, safety and regulatory status of SGLT2 inhibitors: Focus on canagliflozin", Nutrition \& Diabetes, (doi: 10.1038/nutd.2014.40).

[41]Bonora BM, Avogaro A, Fadini GP, "Extraglycemic Effects of SGLT2 Inhibitors: A Review of the Evidence", Diabetes, Metabolic Syndrome and Obesity: Targets and Therapy, (pp. 161-174).

[42]Hsia, Daniel S, (2017). "An update on sodium-glucose cotransporter-2 inhibitors for the treatment of diabetes mellitus", Current opinion in endocrinology, diabetes, and obesity, (pp. 73-79).

[43] Whalen K, Miller S, Onge ES. (2015). The Role of Sodium-Glucose Co-Transporter 2 Inhibitors in the Treatment of Type 2 Diabetes, Clinical Therapeutics, (pp. 1150-1166).

[44] Sonesson C, Johansson PA, Johnsson E, Gause-Nilsson I. (2015). Cardiovascular effects of dapagliflozin in patients with type 2 diabetes and different risk categories: a metaanalysis, Cardiovascular Diabetology, 2016.

[45]Wilcox, Gisela, (2005). Insulin and insulin resistance, The Clinical biochemist. Reviews, (pp. 19-39).

[46] "Handbook of Diabetes, 4th Edition, Excerpt \#4: Normal Physiology of Insulin Secretion and Action". Diabetes In Control. A free weekly diabetes newsletter for Medical Professionals. 